\title{
Temporal Variation in Forest Bird Survey Data from Tutuila Island, American Samoa ${ }^{1}$
}

\author{
Holly B. Freifeld, ${ }^{2}$ Chris Solek, ${ }^{3}$ and Ailao Tualaulelei ${ }^{4}$
}

\begin{abstract}
Avian census data from tropical Pacific islands often are limited to brief, one-time surveys. These efforts yield information about species' presence and distribution but reveal little about variation in abundance through time. This variation may be important for refining and optimizing survey methods and, in turn, assessing habitat preferences, population status, activity patterns, or the impact of disturbance on the abundance and distribution of island birds. The objective of this study was to determine if intra- or interannual patterns exist in the recorded abundance of resident land birds. Forest birds on Tutuila Island, American Samoa, were surveyed each month from 1992 to 1996 at 35 stations on six transects distributed around the island. We used multiple regression techniques to determine that seasonal patterns in detected abundance exist in several species, most notably the Purple-capped Fruit-dove, Ptilinopus porphyraceus, and the Wattled Honeyeater, Foulebaio carunculata. Intraannual patterns may be associated with seasonally variable vocalizations or with concentrations of birds at particular resources. Interannual trends in abundance were not islandwide for any native species during the study period; they were localized and as such may be attributable to small-scale changes in habitat rather than to overall changes in population size. The results of this study, especially that the abundance of nonmigratory island birds is seasonally variable, reinforce the importance of year-round monitoring in the study and conservation of Pacific birds.
\end{abstract}

Fluctuations in animal populations may be episodic or cyclic or both and may take

\footnotetext{
1 This research was supported by the Federal Aid in Wildlife Restoration Act (grant to American Samoa Department of Marine and Wildlife Resources), a University of Oregon Doctoral Dissertation Fellowship (HBF), and the National Science Foundation (grant EAR9714819 to D. W. Steadman). Manuscript accepted 3 June 2003.

2 Correspondence: U.S. Fish and Wildlife Service, Pacific Islands Fish and Wildlife Office, P.O. Box 50088, Honolulu, Hawai'i 96850 (phone: 808-792-9400; fax: 808-792-9581; E-mail: Holly_Freifeld@fws.gov).

${ }^{3}$ Department of Environmental Science, Policy and Management, 145 Mulford Hall, no. 3114, University of California, Berkeley, California 94720-3114.

${ }^{4}$ Department of Marine and Wildlife Resources, American Samoa Government, P.O. Box 3730, Pago Pago, American Samoa 96799.
}

Pacific Science (2004), vol. 58, no. 1:99-117

(C) 2004 by University of Hawai'i Press

All rights reserved place on several time scales. An understanding of temporal variation in bird detection is necessary to use survey data to determine habitat preferences and conservation priorities. For example, if certain species were more vocal or mobile during particular seasons, such as breeding or fruiting seasons, the detected abundance and distribution of birds would depend upon the time of year during which a survey were conducted. Time-series data help minimize the influence of temporary, anomalous conditions (e.g., unusually high temperatures or precipitation during 1 month) on the relative abundance of birds recorded among sites and forest types.

Pacific islands provide an ideal opportunity to investigate temporal patterns in tropical bird abundance under relatively controlled conditions. In contrast with the continental Tropics, where land-bird communities are diverse and temporal patterns are strongly influenced by altitudinal gradients in food abundance and by latitudinal and altitudinal 
migration (Levey 1988, Innis 1989, Loiselle and Blake 1991), Pacific Island land-bird communities generally are depauperate, and most species are nonmigratory (Pratt et al. 1987). The isolation of land masses in the South Pacific discourages regular or seasonal (climate-driven) interisland movement by forest birds. Fluctuations in the observed abundance of land birds over time, therefore, typically are linked with intraisland events and processes rather than with events occurring in a nearby or surrounding land area.

On Pacific islands, as is the case virtually everywhere, populations of native biota are threatened by an array of anthropogenic pressures (Fosberg 1965, King 1985, Loope et al. 2001). On these islands, such directional and often cumulative pressures are superimposed on natural disturbance regimes, such as hurricanes. Natural and human disturbance together influence fluctuations in availability of habitat and resources, and in the incidence and abundance of bird species.

Time-series survey data rarely are available for assessing the status of populations, systematic seasonal variation, and the impacts of environmental change on Pacific island birds and their habitats. Our knowledge of Pacific birds in many cases is based on only a few weeks or months of surveys that at best are repeated at intervals of years (e.g., Engbring and Ramsey 1989, Steadman and Freifeld 1998, Buden 2000). To maximize areal coverage, brief, one-time surveys often involve large numbers of observers (possessing various levels of skill and experience), and repeated surveys often have little or no continuity of observers (Thomas 1996). Furthermore, the use of survey data to estimate absolute abundance is fraught with analytical problems (see Thomas 1996 and references therein). The variable circular plot (VCP) method often has been used in island bird surveys. Distance estimation in VCP surveys is intended to provide data for deriving species density per unit area and, in turn, to calculate population estimates (Scott et al. 1981, Buckland et al. 1993, Fancy 1997).

Seventeen species of land birds inhabit Tutuila Island, American Samoa (Watling 1982, Pratt et al. 1987). Of these, 12 are na- tive residents, one is a wintering migrant, and four are nonnative. All genera present in American Samoa are widespread in the tropical Pacific, and all but one species, the Samoan Starling, Aplonis atrifusca (endemic to the Samoan Archipelago), are found through most or all of Samoa, Tonga, Fiji, and associated islands (Watling 2001).

Assessment of survey data from Tutuila indicated that forest bird numbers declined steeply from 1986 levels subsequent to severe hurricanes in 1990 and 1991 (Engbring and Ramsey 1989, Department of Marine and Wildlife Resources 1994). As a result of this assessment, a monthly forest bird monitoring program was developed, and the government of American Samoa enacted a ban on the hunting of native birds and bats in 1992 . We continued the monitoring program from 1994 to 1996 . This series of bird surveys is unique in the tropical Pacific because it was monthly rather than annual, it was conducted by only three observers, and the methodology was consistent. The objectives of this research were to monitor the status of forest birds on Tutuila and to determine whether systematic temporal patterns exist in the recorded abundance of nonmigratory island birds.

MATERIALS AND METHODS

\section{Study Site}

Tutuila Island $\left(14^{\circ} 19^{\prime} \mathrm{S}, 170^{\circ} 44^{\prime} \mathrm{W} ; 137\right.$ $\mathrm{km}^{2}$ ) is the largest of the seven islands composing the U.S. Territory of American Samoa, located in the central Pacific (Figure 1). Tutuila is a heavily eroded volcanic fragment with extremely steep topography and a maximum elevation of $653 \mathrm{~m}$. Native forest composes roughly $60 \%$ of the island's vegetation cover (Figure 1). Mature rain forest is restricted to the least accessible areas and upper elevations of the island (about 34\% of the total land area). The remainder of the island supports a combination of native secondary forest, plantations, and managed vegetation in villages and urban areas. The human population of Tutuila was about 68,000 in 2002 and growing at an annual rate of $2.31 \%$ (Central Intelligence Agency 2002). The climate in 


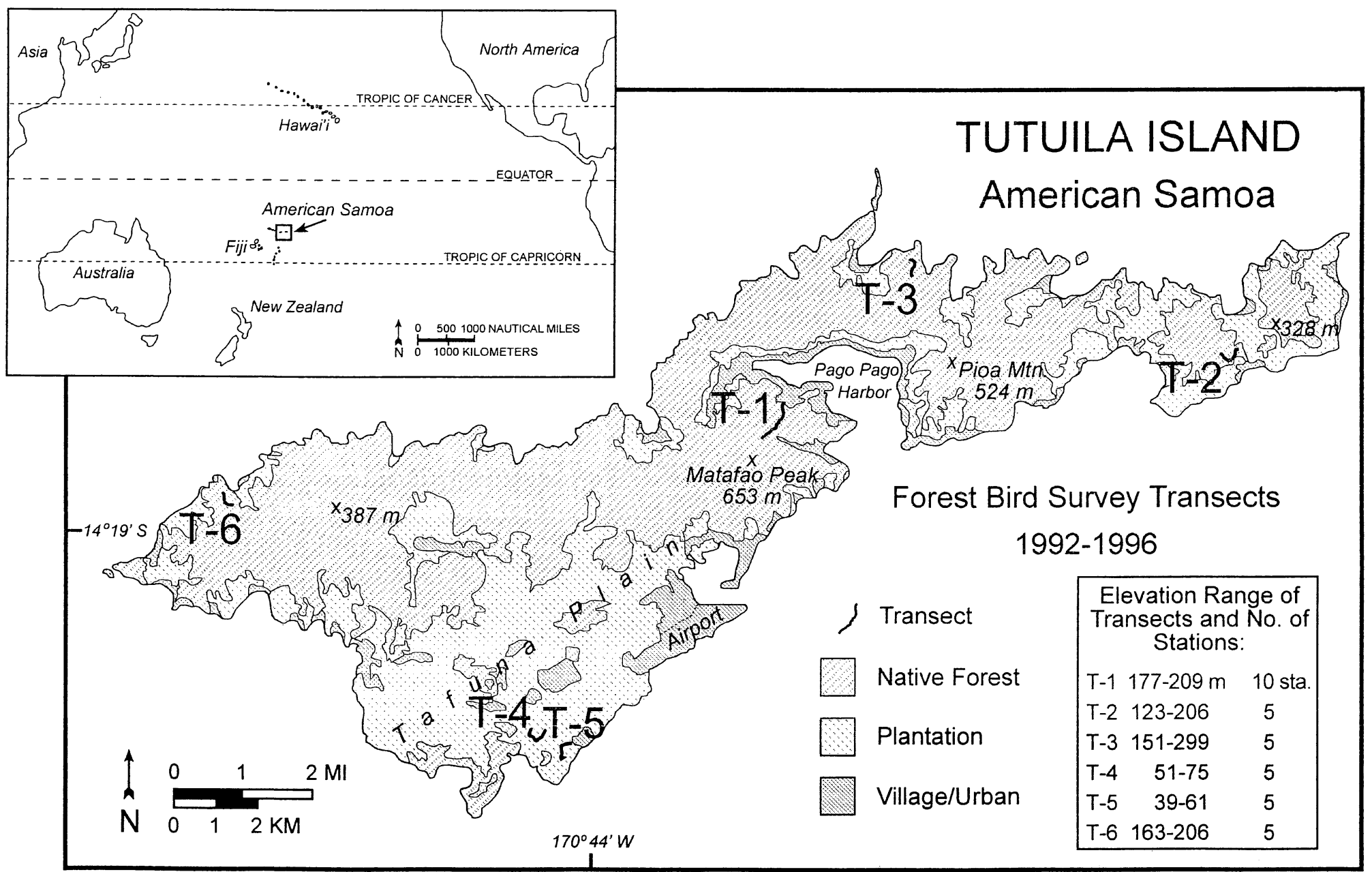

FIGURE 1. Forest bird survey transects and general vegetation on Tutuila Island, American Samoa. Vegetation information is from NOAA aerial photographs (1984). 
American Samoa is moist tropical, with average annual temperatures of $26-28^{\circ} \mathrm{C}$. Annual rainfall averages ca. $400 \mathrm{~cm}$. Maximum temperatures and precipitation occur between December and April (National Oceanic and Atmospheric Administration 1996).

\section{Bird Surveys}

Forest birds were surveyed each month from September 1992 through August 1996 at 35 stations located along six transects distributed around Tutuila (Figure 1). Stations were located 100 to $150 \mathrm{~m}$ apart, and each transect contained 5 to 10 stations. Transects deliberately were placed to sample a wide range of habitats (Freifeld 1999). Some transects traversed relatively homogeneous conditions of elevation and forest type; others traversed gradients of elevation, forest type, and/or human disturbance.

We counted birds using the variable circular plot (VCP) method (Reynolds et al. 1980). All data were collected by P. W. Trail (1992 to 1994), A.T. (1992 to 1996), and H.B.F. (1994 to 1996). All counts were conducted between sunrise (0530-0600 hours) and 1000 hours (Blake 1992). Two observers conducted most counts and then for consistency compared numbers for each species in the field at the conclusion of each 8-min count. We included only one observer's data for each count in the data analysis. We acknowledge that the use of three observers may have introduced some artificial variation to the data. We believe that the long duration of each observer's participation (2 to 4 yr), the presence of one "continuity" observer throughout (A.T.), and the use in our analysis of A.T.'s data whenever available minimizes this potential variation.

We conducted 1657 individual 8-min counts at 35 stations over 48 months. Rainy or windy conditions occasionally prevented counts at individual stations on a particular day, and sometimes logistics did not permit revisiting the station during the same month. Thus, the number of counts conducted at individual stations varied between 46 and 48 .

We found that distances estimated for different species in various forest types were highly unreliable, even for observers with years of experience on Tutuila and in spite of calibration exercises (H.B.F., unpubl. data). Furthermore, the columbids in particular are ventriloquial, and accurate distance estimation for these species is extremely difficult (see also Scott et al. 1981). Species densities and absolute abundances derived from such data consequently should be treated with great caution. Craig (1996) made a similar observation of VCP data he collected on Saipan (Commonwealth of the Northern Mariana Islands).

Because of the difficulty of accurately estimating densities, we considered in our analysis only the actual number of birds recorded. Although we recorded distance estimates for every bird detected according to the standard field protocol for VCP surveys, we used these estimates only as a means of keeping track of birds and avoiding double-counting during the actual 8-min count. We did not use distance estimates to calculate effective detection radii, densities, or absolute abundances for each species.

\section{Data Analysis}

To detect interannual and seasonal fluctuations for each species, we used a multiple regression model (Neter et al. 1983:226-263). The regression model included terms to describe 6- and 12-month-long cycles and linear, quadratic, and cubic trends in the data.

The model is

$$
Y_{t}=T_{t}+S_{t}+I_{t}
$$

where $Y_{t}$ is the raw census data, $T_{t}=b_{0}+$ $b_{1} t+b_{2} t^{2}+b_{3} t^{3}$ is the interannual polynomial trend component, $S_{t}=b_{4} \sin (2 \pi t / 12)+b_{5}$. $\cos (2 \pi t / 12)+b_{6} \sin (4 \pi t / 12)+b_{7} \cos (4 \pi t / 12)$ is the seasonal component, and $I_{t}=e_{t}$ is the irregular or "noise" component, where $t=1, \ldots 48$ months, $b_{1}, \ldots, b_{7}$ are regression coefficients for each term, and the $e_{t} \mathrm{~s}$ are regression residuals, which we assumed to be independent, identically distributed random variables (Neter et al. 1983:110). We inspected residual scatter diagrams, normal probability plots, and autocorrelation functions for each regression to verify this 
assumption. We determined the seven regression coefficients by ordinary least squares (OLS) using Minitab (1994), and we checked the assumptions underlying the use of OLS using standard diagnostic analysis (Neter et al. 1983:109-132, Weisberg 1985:106-127). The regression analysis included calculation of degrees of freedom and a $95 \%$ confidence interval, thus ensuring that significant results reflected an adequate sample size. The inclusion of two sets of trigonometric terms in the model allowed the seasonal component to fit both annual and semiannual "cycles" in the abundance data, if present. The use of a third-order polynomial allowed for a flexible trend component with two inflections. This particular model formulation allowed the level of the dependent variable to change over time while the seasonal cycle was held fixed. It is possible to specify a model that would allow for a temporally evolving seasonal cycle, but the limited length of the record here $(4 \mathrm{yr})$ would not allow such a model to be fitted reliably.

We compiled information on the nesting behavior and phenology of Samoan forest birds from several sources to interpret seasonal patterns in the census data. Unfortunately, no detailed life history studies of these species are available. We relied on published observations (Watling 1982, Pratt et al. 1987) and personal observations, as well as a study of molt and breeding condition in museum specimens (Banks 1984) for life history information. We used raw data from Engbring and Ramsey's (1989) 1986 survey to assess the relative abundance of forest birds on Tutuila before the 1990 and 1991 hurricanes.

\section{RESULTS}

Our surveys recorded 16 of the 17 landbird species that occur on Tutuila: 12 resident natives, three nonnatives, and one nonbreeding migrant (Table 1). The one remaining landbird species, the nonnative but localized Rock Dove, Columba livia Gmelin, was not recorded. We analyzed variation in recorded abundance of the six most commonly recorded native landbirds. The most abundant species were the Wattled Honeyeater, Foule- baio carunculata Gmelin; Samoan Starling, Aplonis atrifusca Peale; and Purple-capped Fruit-dove, Ptilinopus porphyraceus Temminck, and they also were the most frequently observed species (recorded during 95, 92, and $62 \%$ of all surveys, respectively). The other three species that were observed frequently but were not as abundant were the Pacific Pigeon, Ducula pacifica Gmelin (32\%); Collared Kingfisher, Halcyon chloris Scopoli (41\%); and Cardinal Honeyeater, Myzomela cardinalis Gmelin (44\%). The remaining species were not analyzed because they were recorded during too few surveys $(<20 \%)$ to yield meaningful results.

The six most common landbirds exhibited little obvious change in abundance between years, but several species showed strong seasonal fluctuations in abundance (Figure 2). The columbids in particular showed a regular, annual pattern of high and low detections in the dry and wet seasons, respectively. Seasonal variation also was discernable for the Samoan Starling, Wattled Honeyeater, and Collared Kingfisher.

We compared the results of the regression-based analysis of the census data by plotting four series for each taxon: the raw census data, the interannual trend component of the analysis, the seasonal component, and the irregular or residual component (Figure 3 ). The components summarized patterns in the survey data and provided a focus for interpretation of the underlying ecological processes.

The interannual trend component for the Purple-capped Fruit-dove (Figure $3 b$ ) showed no consistent pattern among stations between 1992 and 1996 and apparently accounted for little of the total temporal variability. Significant interannual trends occurred at some stations, which may imply variation over time in the environment at these stations. Because the regression model contained a cubic term (as well as linear and quadratic terms), the trend component sometimes showed two distinct inflections. Although these inflections represented real variation in the data detected by the regression model, they likely were not of biological importance. Roughly one-third of the stations showed this pattern (Figure 
TABLE 1

Landbird Species of Tutuila Island

\begin{tabular}{|c|c|c|c|}
\hline Species & Status $^{a}$ & Guild $^{b}$ & $\begin{array}{c}\text { Frequency } \\
\text { (\% of } 1,657 \text { Counts) }\end{array}$ \\
\hline $\begin{array}{l}\text { Banded Railc } \\
\text { Gallirallus philippensis }\end{array}$ & $\mathrm{N}$ & o & 7 \\
\hline $\begin{array}{l}\text { Purple Swamphen }{ }^{c} \\
\text { Porphyrio porphyrio }\end{array}$ & $\mathrm{N}$ & o & 3 \\
\hline $\begin{array}{l}\text { Rock Doved } \\
\text { Columba livia }\end{array}$ & I & $\mathrm{f}$ & - \\
\hline $\begin{array}{l}\text { Many-colored Fruit-dove } \\
\text { Ptilinopus perousii }\end{array}$ & $\mathrm{N}$ & $\mathrm{f}$ & 2 \\
\hline $\begin{array}{l}\text { Purple-capped Fruit-dove } f \\
\text { Ptilinopus porpbyraceus }\end{array}$ & $\mathrm{N}$ & $\mathrm{f}$ & 62 \\
\hline $\begin{array}{l}\text { Pacific Pigeong } \\
\text { Ducula pacifica }\end{array}$ & $\mathrm{N}$ & $\mathrm{f}$ & 32 \\
\hline $\begin{array}{l}\text { Long-tailed Cuckoo }{ }^{e} \\
\text { Eudynamis taitensis }\end{array}$ & M & $\mathrm{i}, \mathrm{o}$ & 0.8 \\
\hline $\begin{array}{l}\text { Barn Owl }{ }^{c} \\
\text { Tyto alba }\end{array}$ & $\mathrm{N}$ & c & 0.4 \\
\hline $\begin{array}{l}\text { White-rumped Swiftlet }{ }^{c} \\
\text { Collocalia spodiopyoia }\end{array}$ & $\mathrm{N}$ & $\mathrm{i}$ & 13 \\
\hline $\begin{array}{l}\text { Collared Kingfisherg } \\
\text { Halcvon cbloris }\end{array}$ & $\mathrm{N}$ & i,c & 41 \\
\hline $\begin{array}{l}\text { Red-vented Bulbul }{ }^{d} \\
\text { Pycnonotus cafer }\end{array}$ & I & f,o & - \\
\hline $\begin{array}{l}\text { Samoan Starling } f \\
\text { Aplonis atrifusca }\end{array}$ & $\mathrm{E}$ & f,o & 92 \\
\hline $\begin{array}{l}\text { Polynesian Starling } c \\
\text { Aplonis tabuensis }\end{array}$ & $\mathrm{N}$ & $\mathrm{f}, \mathrm{i}$ & 17 \\
\hline $\begin{array}{l}\text { Jungle Myna }{ }^{d} \\
\text { Acridotheres fuscus }\end{array}$ & I & i,o & - \\
\hline $\begin{array}{l}\text { Common Myna }{ }^{d} \\
\text { Acridotheres tristis }\end{array}$ & I & $\mathrm{i}, \mathrm{o}$ & - \\
\hline $\begin{array}{l}\text { Cardinal Honeyeater }{ }^{g} \\
\text { Myzomela cardinalis }\end{array}$ & $\mathrm{N}$ & $\mathrm{n}, \mathrm{i}$ & 44 \\
\hline $\begin{array}{l}\text { Wattled Honeyeater } f \\
\text { Foulebaio carunculata }\end{array}$ & $\mathrm{N}$ & $\mathrm{n}, \mathrm{i}$ & 95 \\
\hline
\end{tabular}

Note: Frequency data are presented only for native species recorded during surveys, 1992-1996. Guild codes refer to primary and secondary diet, after Watling (1982) and Trail (1994).

${ }^{a} \mathrm{~N}$, native; E, endemic; I, introduced nonnative; $M$, migrant (nonbreeding).

${ }^{b}$ o, omnivore; $\mathrm{f}$, frugivore; c, carnivore; $\mathrm{i}$, insectivore; $\mathrm{n}$, nectarivore.

${ }^{c}$ Not included in analysis; not adequately sampled.

${ }^{d}$ Not included in analysis; nonnative species.

${ }^{e}$ Not included in analysis; rare.

$f$ Included in analysis; abundant.

$g$ Included in analysis; less abundant.

3b). However, the absolute amount of interannual variation in mean abundance found at these stations is low; most often the change was less than one bird during the $4 \mathrm{yr}$.

The regression equation was constructed to elucidate 6- and 12-month patterns in the raw data (Figure 3c); this periodicity is most likely if birds are tracking seasonal (climatic) variations. The seasonal component thus was the same from one year to the next. In the case of Purple-capped Fruit-doves, the seasonality in the raw data was so similar from year to year and among stations that the regression results described a very clear, syn- 

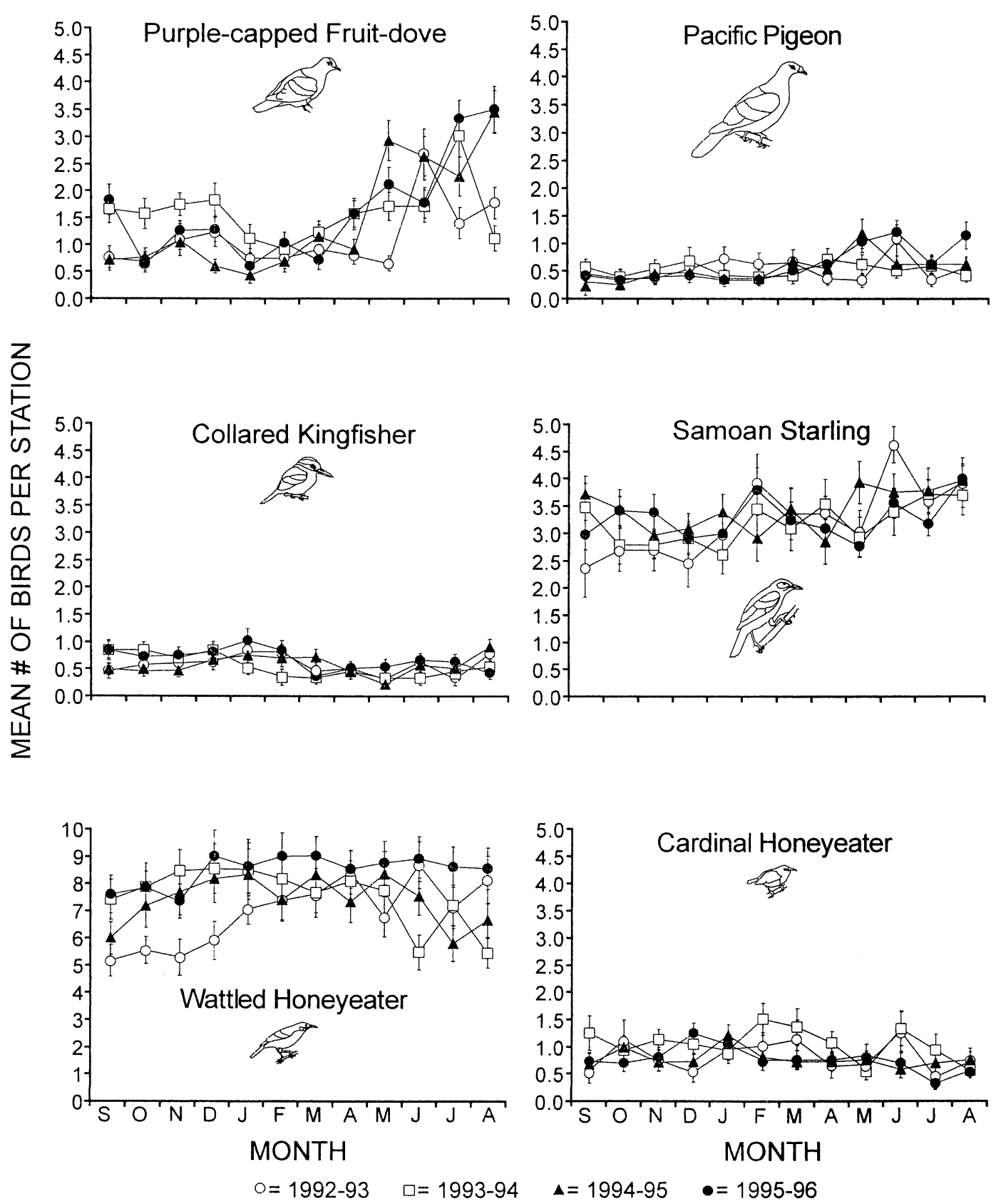

Figure 2. Means and standard errors of recorded abundance for the six most common native species of Samoan forest birds at 35 stations on Tutuila Island. 


\section{Purple-capped Fruit-dove \\ Ptilinopus porphyraceus}
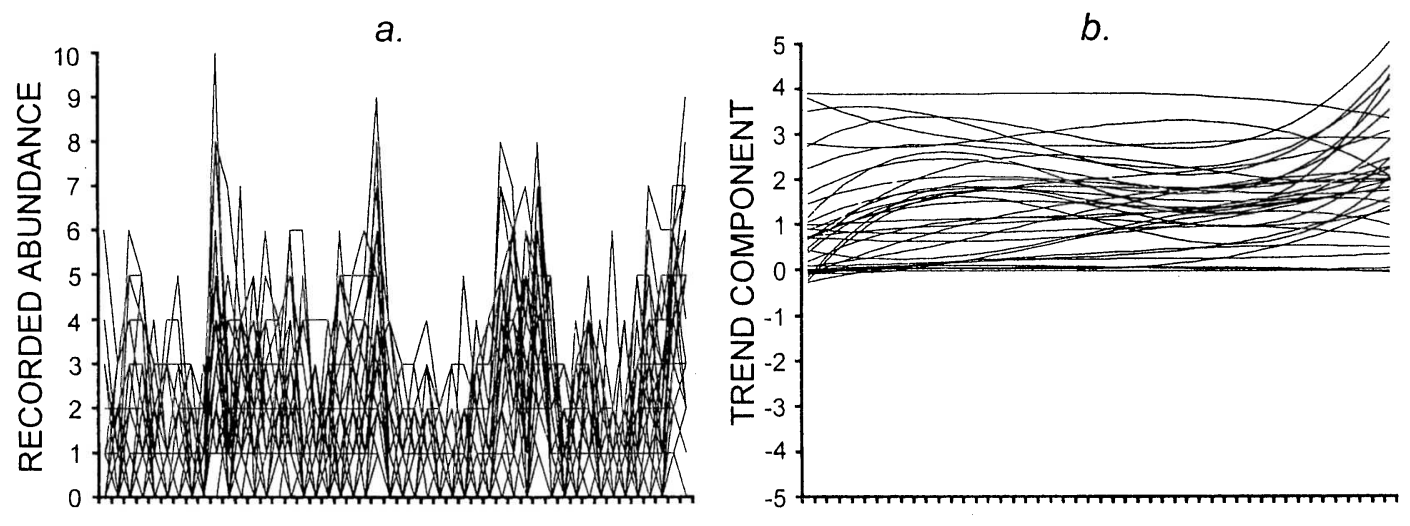

C.
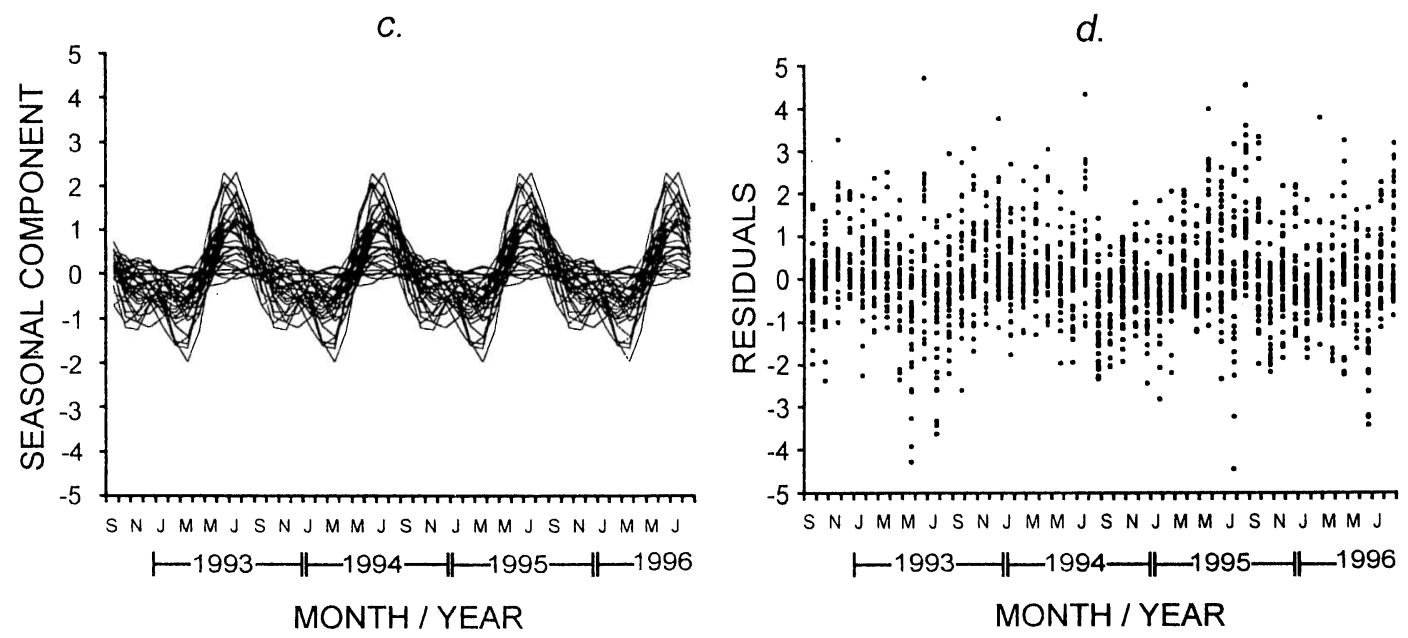

Figure 3. Multiple regression analysis of survey data for the Purple-capped Fruit-dove, Ptilinopus porpbyraceus. Each line represents one of the 35 survey stations. $a$, raw data; $b$, the interannual trend component $\left(T_{t}\right) . Y$ axis values are the sum of regression coefficients describing the interannual variation in 48 months of data; no clear increase or decrease is evident; $c$, the seasonal component $\left(S_{t}\right)$, which shows a 1 -yr pattern repeated four times (for comparison with the raw data). $Y$ axis values are the sum of regression coefficients describing intraannual variation; $d$, the residuals of the regression equation $\left(I_{t}\right)$ for each station.

chronous pattern for one modeled year. The amplitude of this seasonal variation (up to four birds) likely had biological significance (see Discussion). We found no systematic variation in the residual components (Figure $3 d)$; this suggests that the regression assumptions were not seriously violated.
Among 210 regression analyses for each component, $5 \%$ of the $F$ statistics would be significant $(P \leq 0.05)$ by chance alone. In fact, however, a far greater proportion of $F$ statistics was significant (28\% for interannual trend, $23 \%$ for seasonality; see Appendix for tables of $F$ statistics and $P$ values). All spe- 
cies had significant interannual trends and seasonal changes at two or more stations. Systematic variation thus was characteristic of this data set, although patterns differed among species and stations. Seasonal cycles and interannual trends are patterns that reflect different underlying processes. Therefore, we present separately the results of the seasonality and interannual trend components of the regression analysis.

\section{Seasonality}

The patterns of seasonality in the abundance of bird species varied in amplitude and synchrony across the 35 stations (Figure 4). The abundance of Purple-capped Fruit-doves showed significant $(P \leq 0.05)$ seasonal patterns at $59 \%$ of all stations where they were recorded (Appendix). Wattled Honeyeaters had the next greatest proportion of significant seasonal patterns (26\% of stations), and third was the Samoan Starling (20\%). For the remaining species, fewer than $20 \%$ of stations had significant seasonal patterns. The seasonal component of the regression analysis had visually discernable patterns for five of six species (Figure 4), although not all of these clear, graphical patterns were significant.

The abundance of Purple-capped Fruitdoves showed the most synchronous seasonal cycle, with the high positive deviation, or increase, from the average predicted abundance occurring between June and August (cool/dry season), and the high negative deviation, or decrease, between February and April (hot/ wet season). The abundance of Samoan Starlings had a less synchronous but seasonally similar response, with the increases occurring during the cool/dry season. The pattern for Wattled Honeyeaters showed a broad, low increase extending through most of the hot/ wet season (approximately December-April), with a group of stations peaking at a much higher level in December-January. Collared Kingfishers, although never abundant, had a low but synchronous increase above the average during the hot/wet season. Other species had less-definable seasonal patterns in their abundance, although the detection of all species appeared generally to increase during one season or the other (Table 2).

\section{Interannual Trends}

Although individual stations had significant trends in species abundance over the $4 \mathrm{yr}$, a consistent trend of increase or decrease was not evident across all stations for any species (Figure 5). Trends in the abundance of each species were features of particular stations or spatially clumped groups of stations. Wattled Honeyeaters, Samoan Starlings, and Purplecapped Fruit-doves had the greatest number of stations with significant changes in abundance between 1992 and 1996. Wattled Honeyeaters had significant $(P \leq 0.05)$ trends at $49 \%$ of all stations. Purple-capped Fruitdoves and Samoan Starlings had significant interannual trends at 38 and $37 \%$ of stations, respectively. At a few stations, there was an increase in recorded numbers of Purplecapped Fruit-doves between 1992 and 1996, and at other stations there was a decline in numbers of Samoan Starlings and Cardinal Honeyeaters.

PREHURRICANE FOREST BIRD ABUNDANCE. Five weeks of surveys on Tutuila in June and July of 1986 using methods identical to ours (Engbring and Ramsey 1989) provided one short-term estimate of prehurricane abundance levels, although the differences in station locations and observers and the timing and duration of these surveys prohibit rigorous comparison. Nevertheless, a qualitative comparison of the 1986 data (Engbring and Ramsey 1989) with a subset of the 1992-1996 data suggests that significant declines in these six bird species did occur in American Samoa after 1986 (Figure 6). Presumably these declines were attributable to Hurricanes Ofa (1990) and Val (1991), which were both unusually severe storms. In this comparison, numbers of most species have remained at less than half of their 1986 average observed abundance.

\section{DISCUSSION}

Seasonal changes in detection account for the majority of the variation in the observed abundance of these Samoan birds between 

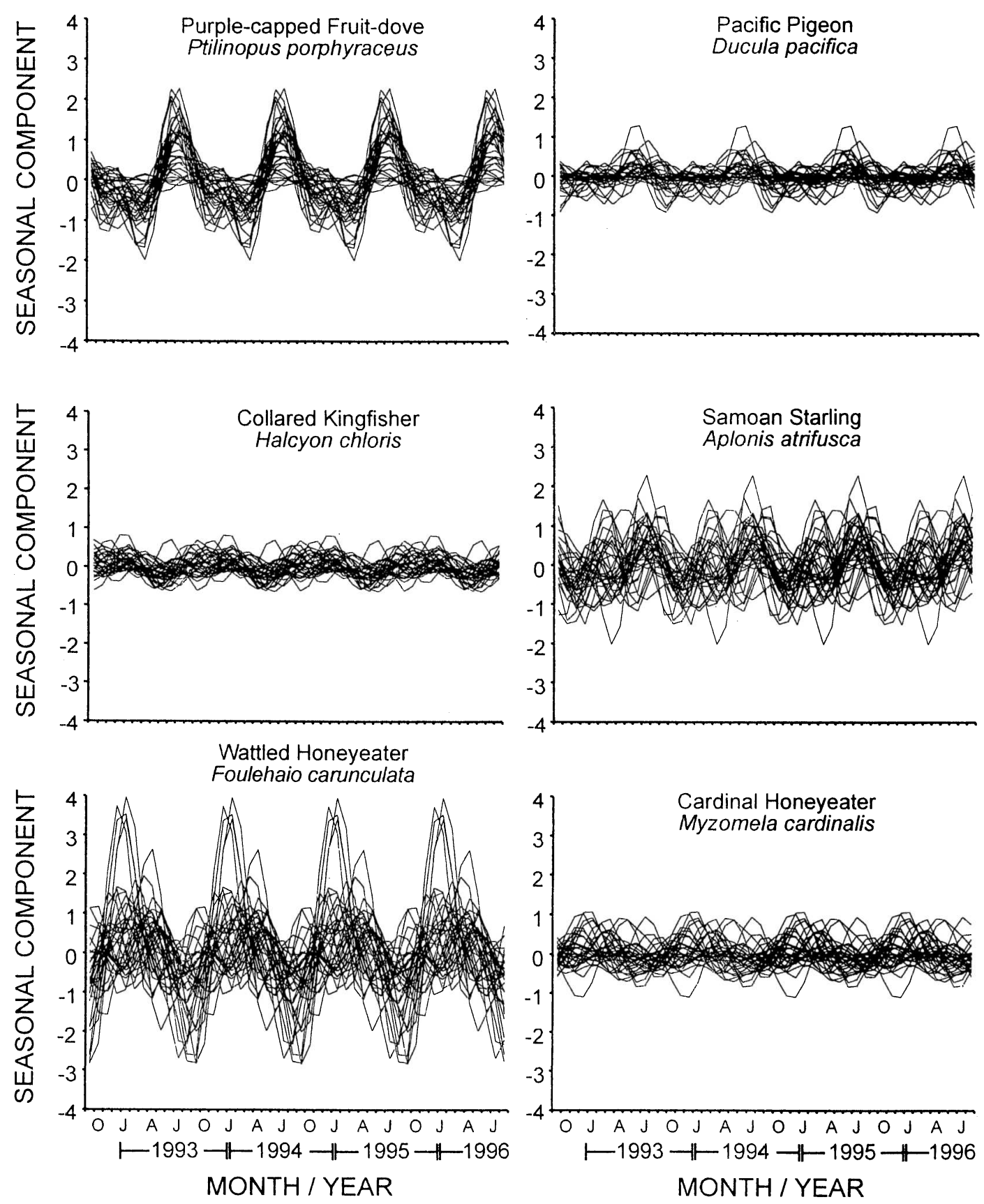

Figure 4. Seasonal component $\left(S_{t}\right)$ of multiple regression analysis for six native Samoan forest birds. Each line represents one of 35 stations where birds were surveyed each month. Seasonal patterns are expressed as positive or negative deviations from a baseline of average predicted abundance represented by zero. 
TABLE 2

Greatest Mean Increases above and Decreases below $( \pm S E)$ a Baseline of Average Detected Abundance Predicted by Multiple Regression for Six Species of Samoan Forest Birds

\begin{tabular}{lll}
\hline \hline Species & \multicolumn{1}{c}{ High } & \multicolumn{1}{c}{ Low } \\
\hline Purple-capped Fruit-dove & $0.93 \pm 0.11$ (July) & $-0.64 \pm 0.09$ (March) \\
Pacific Pigeon & $0.20 \pm 0.10$ (June) & $-0.12 \pm 0.04$ (October) \\
Samoan Starling & $0.53 \pm 0.10$ (July) & $-0.45 \pm 0.07$ (November) \\
Collared Kingfisher & $0.15 \pm 0.04$ (January) & $-0.20 \pm 0.04$ (May) \\
Wattled Honeyeater & $0.61 \pm 0.21$ (January) & $-0.82 \pm 0.14$ (August) \\
Cardinal Honeyeater & $0.14 \pm 0.06$ (January) & $-0.13 \pm 0.05$ (July) \\
\hline
\end{tabular}

Note: These pairs of means illustrate the average variation in detection of these species at 35 stations during 1 yr modeled by the regression analysis (see Figures 3 and 4). Most species were detected in greater abundance during either the dry season (MayNovember) or the wet season (December-April).

1992 and 1996. Life history traits that vary among species may account for this seasonality, but specific data about these traits are lacking for most species. Because of the length of the record (only $4 \mathrm{yr}$ ), we cannot conclude from the interannual variations we observed in some species that overall population changes took place, except perhaps in the Wattled Honeyeater. These changes do suggest, however, that both the monitoring and analytic methods are sensitive enough to yield information about population changes in these species over a longer period. The layout of survey stations could be altered to target vocal, native species with insufficient observations in this data set to document either intra- or interannual patterns, such as the Many-colored Fruit-dove, Ptilinopus perousii Peale, and the Polynesian Starling, Aplonis tabuensis Gmelin. For other native species not included in the current analysis, different survey methods may be needed.

\section{Seasonal Variation in Abundance}

Seasonal patterns in the observed abundance of Samoan birds may be influenced by one of two situations. First, the number of birds may be essentially constant at a station yearround, but their vocalization and, hence, detection may change seasonally. For example, columbids typically are more vocal during courtship and nesting. Second, the actual number of birds present at a station may change seasonally. Because Samoan land birds are not known to migrate sensu stricto between islands (Pratt et al. 1987, Watling 2001), seasonal changes in numbers would involve local, intraisland movements to exploit resources that are patchily distributed in space and time. Such localized movements have been described in tropical bird communities elsewhere (Levey 1988, Loiselle 1988, Innis 1989), including Hawai'i (Simon et al. 2002). In addition, observed numbers also may increase seasonally with the fledging of young birds. This may be the case for the kingfisher, starling, and honeyeaters, because all apparently engage in frequent contact calling among family members (Dylan Kesler, pers. comm.; H.B.F., pers. obs.). Juvenile pigeons and doves, in contrast, do not vocalize conspicuously until they are mature (Jeffrey Sailer, pers. comm.).

One outstanding feature of the seasonal patterns for the most abundant species shown in Figure 4 is that they varied synchronously. Because the 35 stations represent a range of habitat types, elevations, and locations around the island, this uniformity strongly suggests that no species systematically moved en masse between locations or habitat types during the year.

Given the synchrony among all stations in the Purple-capped Fruit-dove (Figure 4), seasonal patterns in Samoan columbids probably represent changes in detectability rather than in absolute numbers. Craig (1996) drew a similar conclusion about the Mariana Fruitdove, Ptilinopus roseicapilla Lesson, on Saipan 

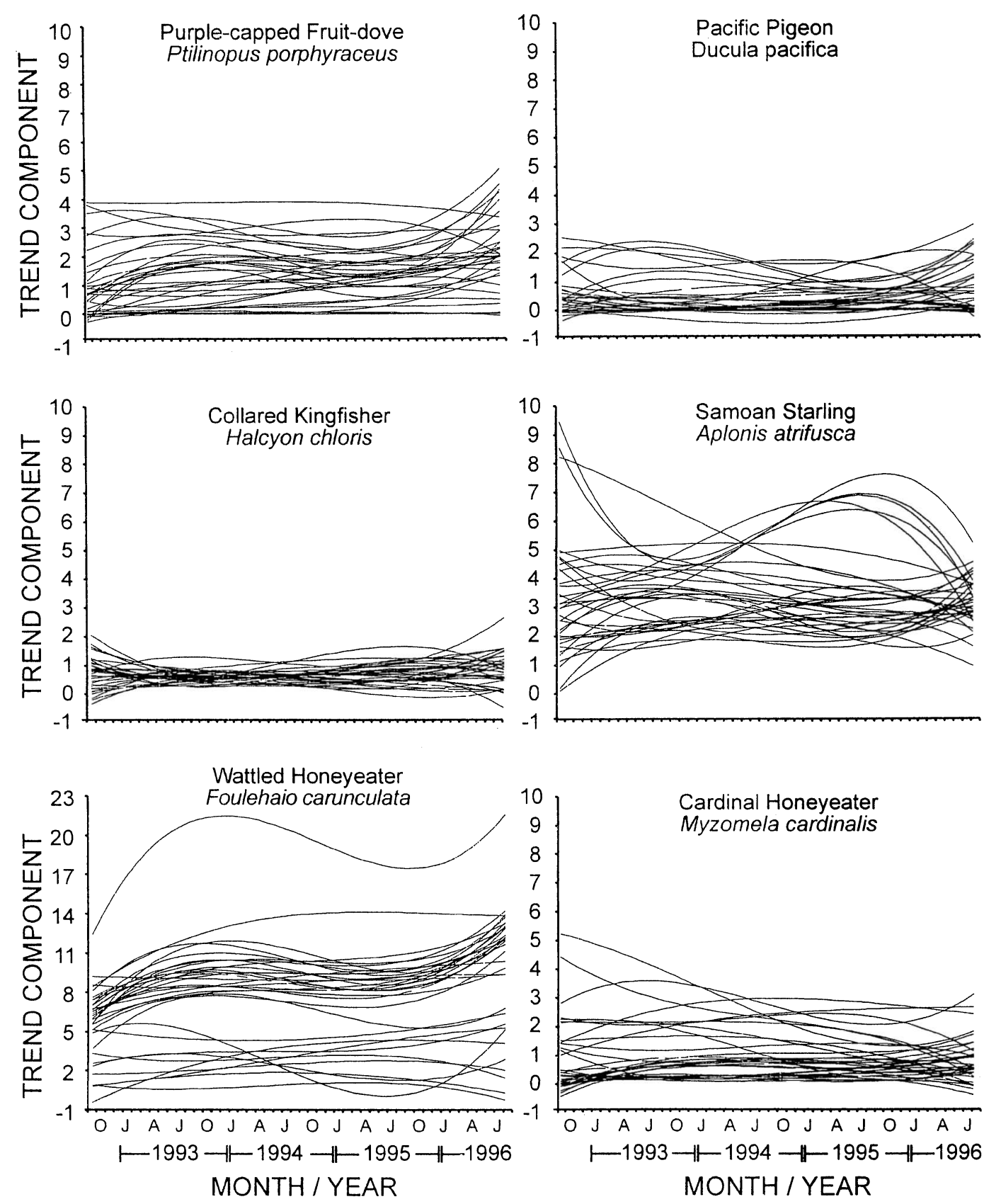

FIGURE 5. Interannual trend component $\left(T_{t}\right)$ of multiple regression analysis for six native Samoan forest birds. Each line represents one of 35 stations on Tutuila Island where birds were surveyed each month (48 months total). Other explanations as in Figures 3 and 4. 


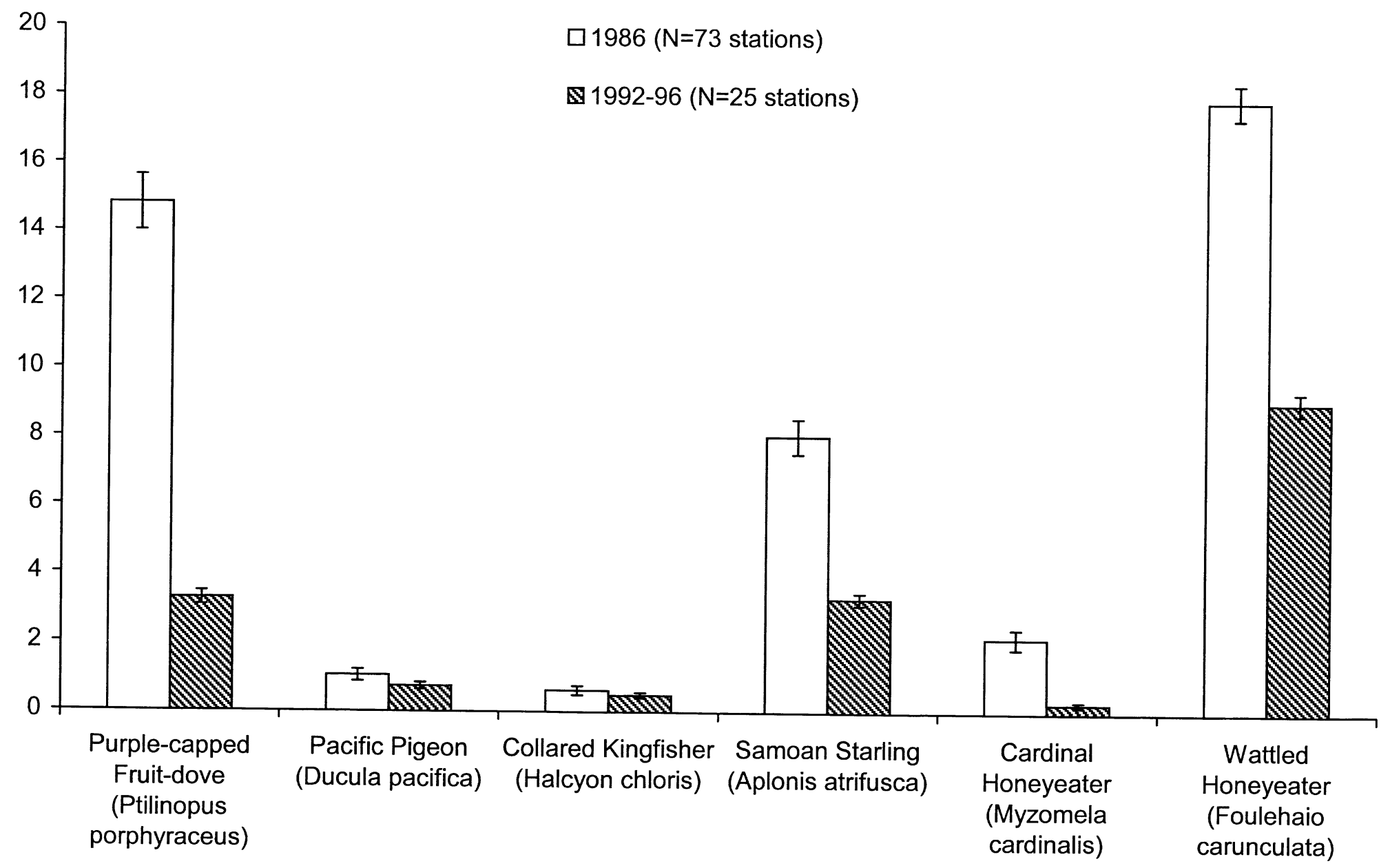

FIGURE 6. Average abundance (mean and standard error) per station of six native Samoan forest birds in 1986 and 1992-1996. Values for 1986 are from surveys in June-July by Engbring and Ramsey (1989) in locations similar to the native forest transects 1, 2, 3, and 6 of the current study (see Figure 1). Data from 1992-1996 are from surveys in
July on these same four transects (25 stations). 
based on comparison of peaks in recorded abundance with observations of nesting activity. Male columbids typically vocalize to defend territories during courtship and nesting (Goodwin 1970; J. Sailer, pers. comm.), and this probably is the case in Samoa. Reproductive activity in Purple-capped Fruit-doves and Pacific Pigeons occurs during the early dry season (June-July), when peak numbers were recorded (pers. obs.; P. Trail, pers. comm.). Gonad measurements from museum specimens provide additional evidence that American Samoan columbids nest during the dry season (Banks 1984).

Breeding condition and molt indicate that the Samoan Starling nests during the dry season as well (Amerson et al. 1982, Banks 1984), which also is when peak abundance was recorded (Figure 4). This season, approximately April through September, also is when Dysoxylum spp., trees species that provide an abundant and preferred food for Samoan Starlings, are fruiting (Trail 1994). Thus, both breeding season vocalization and concentration of birds at food sources may explain the seasonal pattern in the observed numbers of starlings.

In the Wattled Honeyeater, a highly vocal species that nests year-round (H.B.F., pers. obs.; Banks 1984), seasonal variation in detection may be influenced primarily by gregarious concentration to exploit specific resources rather than by breeding behavior (Collins and Briffa 1982, Collins et al. 1983). For example, Wattled Honeyeaters showed a high peak in abundance at four stations in December and January (Figure 4). These stations harbor large, reproductive individuals of Syzygium inophylloides, a native canopy tree that flowers during these months and produces nectar that honeyeaters favor (Trail 1994). We counted the greatest numbers of Wattled Honeyeaters at these stations while they fed on Syzygium nectar.

Collared Kingfishers are solitary or paired birds that vocalize on territories, especially during courtship and nesting (Fry et al. 1992:180; D. Kesler, pers. comm.). Unlike Wattled Honeyeaters, Collared Kingfishers have a well-defined nesting season (Banks 1984; D. Kesler, pers. comm.). The king- fisher's behavior and pattern of detection, then, may reflect territorial vocalization during the hot/wet season.

\section{Interannual Variation in Abundance}

The detection of interannual trends is highly sensitive to abundance (Thomas 1996), and this sensitivity was manifested in two ways here. First, the proportion of stations with significant trend components was greatest in abundant species. Therefore, the lessabundant species, such as the Cardinal Honeyeater and Collared Kingfisher, might have registered an increase or decrease in abundance had they been recorded in higher numbers overall. The absence of evidence thus does not necessarily mean that no interannual changes in abundance occurred. Second, in low-abundance species, a significant increase or decrease at a single station may be biologically insignificant, if the species in question was recorded only once or twice at that station. This is the case for changes in the detected abundance of Pacific Pigeons at a few stations.

No species, with the possible exception of the Wattled Honeyeater, shows overall decline or increase in abundance between 1992 and 1996. The length of this study probably is not sufficient to document long-term, islandwide trends in population nor to evaluate the recovery of some species since Hurricanes Ofa and Val and the associated opportunistic hunting (Trail and Tualaulelei 1992, Craig et al. 1994), although the comparison of our data with those of Engbring and Ramsey (1989) (Figure 6) suggests persistent low numbers. In addition, the lack of information about the life history and movements of these species hinders interpretation of localized changes in abundance in some species. For example, increased detections of Purplecapped Fruit-doves at particular stations over the 4 yr may reflect redistribution of adults in response to changing habitat rather than recruitment of young birds into the population.

\section{Species Excluded from Analysis}

Because of limitations of the survey methodology, our analysis excludes the Banded Rail, 
Gallirallus philippensis Linnaeus, and the White-rumped Swiftlet, Collocalia (Aerodramus) spodiopygia Peale, which both are relatively abundant but vocally cryptic. The survey method and layout of transects did not adequately sample other land-bird species because of their specialization (e.g., Purple Swamphen, Porpbyrio porphyrio Linnaeus, a plantation and wetland bird) or general rarity (e.g., Many-colored Fruit-dove). Some species probably are more abundant than was recorded by our surveys. For example, the Pacific Pigeon apparently is vocally cryptic where it is hunted (Steadman and Freifeld 1998, Steadman and Franklin 2000; H.B.F., pers. obs.), and the Polynesian Starling is more cryptic and perhaps less abundant overall in Samoa than elsewhere in its range (H.B.F., pers. obs.). The Cardinal Honeyeater is most abundant in village and urban habitats (Freifeld 1999), which were not sampled in our study. With these exceptions, the recorded relative abundance of species reported here probably is fairly accurate for the locations and habitats surveyed.

\section{CONCLUSIONS}

Analysis of the 4-yr time series from Tutuila yielded well-defined seasonal patterns in forest birds on this tropical island. Localized interannual changes were registered in the abundance of some species, indicating the value of continued monitoring for the detection of long-term population trends. The seasonal variation in bird numbers documented on Tutuila indicates that data from single surveys of island birds may inaccurately record relative abundance and fail to record systematic variability over time. On Tutuila, for example, if Purple-capped Fruit-doves are sampled only during October, the result will be lower recorded abundance overall and more homogeneous distribution among habitats than if this species is sampled during June. These important artifacts of limited surveys may be expected in any Pacific Island environment; a baseline monitoring program thus is essential to accurately establish the distribution and relative abundance of native island birds for conservation purposes. In
American Samoa, given the increasing human population and the likely increase in land clearing and development, continued monitoring of land birds is critical in tracking species' abundance over longer periods.

At least $1 \mathrm{yr}$ of monthly surveys at a welldispersed and widely representative array of sites on an island is required to document the seasonal patterns of detection in most forest bird species. Multiple years may be necessary to capture subtle seasonal variation in uncommon species. This information can be used to guide research priorities and to make efficient decisions about future monitoring and conservation strategies.

Finally, little is known of the resource requirements, reproductive behavior, or population dynamics of Samoan and other Polynesian land birds. Life history and autecological studies are sorely needed to tie the patterns described here to biological traits or ecological requirements that may influence species' responses to environmental change. Such studies will provide valuable information for interpreting temporal variation and assessing conservation issues for forest birds on Tutuila and elsewhere in the Pacific.

\section{ACKNOWLEDGMENTS}

We thank the director, Ufagafa Ray Tulafono, and staff of the Department of Marine and Wildlife Resources of the American Samoa Government (DMWR) for logistical and material support. Pepper Trail provided valuable insights and information throughout. DMWR provided survey data collected by $\mathrm{P}$. Trail and A. Tualaulelei between 1992 and 1994. Fred Ramsey kindly provided raw data from the 1986 bird surveys conducted by the U.S. Fish and Wildlife Service in American Samoa. Patrick Bartlein developed the regression model. Dylan Kesler (USGS-BRD) provided information on Halcyon kingfisher behavior, and Jeffrey Sailer of the Miami Zoo provided information about tropical columbids. We thank P. Bartlein, G. Carr, S. Cook, P. Craig, R. Craig, J. Heath, A. Kratter, D. Leonard Jr., D. Steadman, E. VanderWerf, D. Watling, C. Whitlock, and T. Wesolowski for comments that greatly improved the paper. 


\section{Literature Cited}

Amerson, A. B. J., W. A. Whistler, and T. D. Schwaner. 1982. Wildlife and wildlife habitat of American Samoa. U.S. Fish and Wildlife Service Report, Washington, D.C.

Banks, R. C. 1984. Bird specimens from American Samoa. Pac. Sci. 38:150-169.

Blake, J. G. 1992. Temporal variation in point counts of birds in a lowland wet rainforest in Costa Rica. Condor 94:265275.

Buckland, S. T., D. R. Anderson, K. P. Burnham, and J. L. Laake. 1993. Distance sampling: Estimating abundance of biological populations. Chapman \& Hall, London.

Buden, D. W. 2000. A comparison of 1983 and 1994 bird surveys of Pohnpei, federated states of Micronesia. Wilson Bull. 112:403-410.

Central Intelligence Agency (CIA). 2002. The world factbook. CIA, Government Printing Office, Washington, D.C.

Collins, B. G., and P. Briffa. 1982. Seasonal variation of abundance and foraging of three species of Australian honeyeaters. Aust. Wildl. Res. 9:557-569.

Collins, B. G., P. Briffa, and C. Newland. 1983. Temporal changes in abundance and resource utilization by honeyeaters at Wongamine Nature Reserve. Emu 84:159-166.

Craig, P., T. E. Morrell, and K. So'oto. 1994. Subsistence harvest of birds, fruit bats, and other game in American Samoa, 19901991. Pac. Sci. 48:344-352.

Craig, R. J. 1996. Seasonal population surveys and natural history of a Micronesian bird community. Wilson Bull. 108:246267.

Department of Marine and Wildlife Resources (DMWR). 1994. American Samoa wildlife investigations annual report, fiscal year 1993. American Samoa Government, Pago Pago, American Samoa.

Engbring, J., and F. L. Ramsey. 1989. A 1986 survey of the forest birds of American Samoa. U.S. Fish and Wildlife Service Report, Honolulu, Hawai'i.
Fancy, S. G. 1997. A new approach for analyzing bird densities from variable circularplot counts. Pac. Sci. 51:107-114.

Fosberg, F. R., ed. 1965. Man's place in the island ecosystem. Proc. 10th Pac. Sci. Congr., Honolulu, 1961. Bishop Museum Press, Honolulu, Hawai'i.

Freifeld, H. B. 1998. Temporal and spatial variation in forest birds on Tutuila Island, American Samoa. Ph.D. diss., University of Oregon, Eugene.

1999. Habitat relationships of forest birds on Tutuila Island, American Samoa. J. Biogeogr. 26:1191-1213.

Fry, C. H., K. Fry, and A. Harris. 1992. Kingfishers, bee-eaters, and rollers: A handbook. Princeton University Press, Princeton, New Jersey.

Goodwin, D. 1970. Pigeons and doves of the world. British Museum of Natural History, London.

Innis, G. J. 1989. Feeding ecology of fruit pigeons in subtropical rainforests of southeastern Australia. Aust. Wildl. Res. 16:365-394.

King, W. B. 1985 . Island birds: Will the future repeat the past? Pages 3-15 in P. J. Moors, ed. Conservation of island birds. ICBP Technical Publication No. 3. International Council for Bird Preservation, Norwich, England.

Levey, D. J. 1988. Spatial and temporal variation in Costa Rican fruit and fruit-eating bird abundance. Ecol. Monogr. 58:251269.

Loiselle, B. A. 1988. Bird abundance and seasonality in a Costa Rican lowland forest canopy. Condor 90:761-772.

Loiselle, B. A., and J. G. Blake. 1991. Temporal variation in birds and fruits along an elevational gradient in Costa Rica. Ecology 72:180-193.

Loope, L. L., F. G. Howarth, F. Kraus, and T. K. Pratt. 2001. Newly emergent and future threats of alien species to Pacific birds and ecosystems. Pages 291-304 in J. M. Scott, S. Conant, and C. van Riper III, eds. Evolution, ecology, conservation, and management of Hawaiian birds: A vanishing avifauna. Stud. Avian Biol. No. 22.

Minitab. 1994. Statistical software for Win- 
dows, release 10.0. Minitab, Inc., State College, Pennsylvania.

National Oceanic and Atmospheric Administration (NOAA). 1966. Local climatological data: Annual summary with comparative data: Pago Pago, American Samoa (NST). National Climatic Data Center, Asheville, North Carolina.

Neter, J., W. Wasserman, and M. H. Kutner. 1983. Applied linear regression models. Richard D. Irwin, Inc., Homewood, Illinois.

Pratt, H. D., P. Brunner, and D. G. Berrett. 1987. A field guide to the birds of Hawaii and the tropical Pacific. Princeton University Press, Princeton, New Jersey.

Reynolds, R. T., J. M. Scott, and R. A. Nussbaum. 1980. A variable circular-plot method for estimating bird numbers. Condor 82:309-313.

Scott, J. M., F. L. Ramsey, and C. B. Kepler. 1981. Distance estimation as a variable in estimating bird numbers. Pages 334-340 in C. J. Ralph and J. M. Scott, eds. Estimating numbers of terrestrial birds. Stud. Avian Biol. No. 6.

Simon, J. C., T. K. Pratt, K. E. Berlin, J. R. Kowalsky, S. G. Fancy, and J. S. Hatfield. 2002. Temporal variation in bird counts within a Hawaiian rainforest. Condor 104:469-481.

Steadman, D. W., and J. Franklin. 2000. A preliminary survey of the landbirds on Lakeba, Lau Group, Fiji. Emu 100:227235 .
Steadman, D. W., and H. B. Freifeld. 1998. Distribution, relative abundance, and habitat relationships of landbirds in the Vava'u Group, Kingdom of Tonga. Condor 100:609-628.

Thomas, L. 1996. Monitoring long-term population change: Why are there so many analysis methods? Ecology 77:49-58.

Trail, P. W. 1994. The phenology of rainforest plants on Tutuila Island, American Samoa. American Samoa Government Department of Marine and Wildlife Resources Biological Report Series No. 58. Pago Pago, American Samoa.

Trail, P. W., and A. Tualaulelei. 1992. Declines in land bird populations on Tutuila Island, American Samoa, 1986-1992. American Samoa Government Department of Marine and Wildlife Resources Biological Report Series No. 32. Pago Pago, American Samoa.

Watling, D. 1982. Birds of Fiji, Tonga and Samoa. Millwood Press, Wellington, New Zealand.

- 2001. A guide to the birds of Fiji and western Polynesia, including American Samoa, Niue, Samoa, Tokelau, Tonga, Tuvalu, and Wallis-Futuna. Environment Consultants Fiji, Ltd., and South Pacific Regional Environmental Programme, Apia, Samoa.

Weisberg, S. 1985. Applied linear regression: Wiley series in probability and mathematical statistics. John Wiley \& Sons, New York. 
Appendix

\begin{tabular}{|c|c|c|c|c|c|c|c|c|c|c|c|c|}
\hline \multirow[b]{2}{*}{ Station } & \multicolumn{2}{|c|}{$\begin{array}{l}\text { Purple-capped } \\
\text { Fruit-dove, } \\
\text { Ptilinopus } \\
\text { porphyraceus }\end{array}$} & \multicolumn{2}{|c|}{$\begin{array}{l}\text { Pacific } \\
\text { Pigeon, } \\
\text { Ducula } \\
\text { pacifica }\end{array}$} & \multicolumn{2}{|c|}{$\begin{array}{l}\text { Collared } \\
\text { Kingfisher, } \\
\text { Halcyon } \\
\text { cbloris }\end{array}$} & \multicolumn{2}{|c|}{$\begin{array}{l}\text { Samoan } \\
\text { Starling, } \\
\text { Aplonis } \\
\text { atrifusca }\end{array}$} & \multicolumn{2}{|c|}{$\begin{array}{c}\text { Cardinal } \\
\text { Honeyeater, } \\
\text { Myzomela } \\
\text { cardinalis }\end{array}$} & \multicolumn{2}{|c|}{$\begin{array}{c}\text { Wattled } \\
\text { Honeyeater, } \\
\text { Foulehaio } \\
\text { carunculata }\end{array}$} \\
\hline & $F$ & $P$ & $F$ & $P$ & $F$ & $P$ & $F$ & $P$ & $F$ & $P$ & $F$ & $P$ \\
\hline \multicolumn{13}{|c|}{ aterannual trend } \\
\hline 1 & 2.56 & 0.067 & 2.20 & 0.102 & 0.83 & 0.485 & 0.74 & 0.533 & 1.60 & 0.203 & 2.41 & 0.079 \\
\hline 2 & 1.69 & 0.183 & 1.91 & 0.143 & 0.42 & 0.740 & 0.37 & 0.775 & 1.50 & 0.228 & 5.98 & 0.002 \\
\hline 3 & 3.78 & 0.017 & 3.90 & 0.015 & 0.74 & 0.532 & 0.08 & 0.970 & 0.93 & 0.435 & 4.08 & 0.012 \\
\hline 4 & 1.29 & 0.290 & 12.81 & 0.000 & 0.60 & 0.621 & 3.70 & 0.019 & 0.83 & 0.487 & 2.94 & 0.044 \\
\hline 5 & 1.63 & 0.196 & 0.93 & 0.435 & 2.18 & 0.105 & 1.04 & 0.385 & 0.31 & 0.819 & 2.79 & 0.052 \\
\hline 6 & 0.24 & 0.865 & 1.30 & 0.286 & 0.49 & 0.691 & 0.06 & 0.982 & 0.70 & 0.558 & 3.08 & 0.037 \\
\hline 7 & 0.12 & 0.948 & 1.82 & 0.158 & 0.96 & 0.418 & 1.90 & 0.143 & 2.31 & 0.089 & 2.36 & 0.085 \\
\hline 8 & 1.97 & 0.133 & 0.51 & 0.681 & 2.90 & 0.046 & 1.20 & 0.323 & 1.47 & 0.23 & 2.74 & 0.055 \\
\hline 9 & 2.12 & 0.112 & 0.87 & 0.465 & 1.93 & 0.139 & 2.25 & 0.096 & 1.60 & 0.2 & 2.64 & 0.061 \\
\hline 10 & 0.83 & 0.485 & 2.91 & 0.045 & 3.71 & 0.019 & 0.09 & 0.968 & 0.26 & 0.853 & 2.27 & 0.094 \\
\hline 11 & 7.44 & 0.000 & 1.08 & 0.369 & 1.01 & 0.396 & 6.99 & 0.001 & 0.74 & 0.532 & 1.33 & 0.276 \\
\hline 12 & 4.1 & 0.012 & 1.96 & 0.134 & 0.20 & 0.892 & 0.32 & 0.812 & 0.48 & 0.700 & 3.37 & 0.027 \\
\hline 13 & 4.54 & 0.007 & 1.26 & 0.300 & 1.97 & 0.133 & 1.09 & 0.363 & 1.21 & 0.316 & 3.61 & 0.020 \\
\hline 14 & 1.65 & 0.191 & 1.58 & 0.207 & 7.47 & 0.000 & 0.62 & 0.608 & 1.36 & 0.269 & 5.19 & 0.004 \\
\hline 15 & 1.77 & 0.166 & 0.03 & 0.99 & 1.03 & 0.388 & 1.85 & 0.152 & 2.03 & 0.124 & 1.43 & 0.246 \\
\hline 16 & 0.34 & 0.795 & 5.47 & 0.003 & 0.50 & 0.681 & 0.86 & 0.470 & 0.81 & 0.497 & 2.28 & 0.093 \\
\hline 17 & 0.07 & 0.975 & 0.13 & & 1.16 & 0.337 & 1.41 & 0.253 & 0.39 & 0.759 & 3.73 & 0.018 \\
\hline 18 & 0.56 & 0.643 & 0.23 & 0.876 & 1.05 & 0.379 & 3.11 & 0.036 & 6.82 & 0.001 & 0.08 & 0.970 \\
\hline 19 & 2.79 & 0.052 & & & 0.25 & 0.860 & 2.02 & 0.125 & 1.49 & 0.2 & 0.57 & 0.640 \\
\hline 20 & 1.16 & 0.334 & 4.44 & 0.0 & 1.28 & 0.293 & 1.70 & 0.18 & 0.01 & 0.9 & 1.75 & 0.170 \\
\hline 21 & 6.2 & 0.0 & 0.54 & 0.6 & 2.75 & 0.054 & 3.46 & 0.024 & 1.30 & 0.288 & 8.11 & 0.000 \\
\hline 22 & 12.62 & 0.000 & 1.31 & 0.28 & 0.89 & 0.45 & 1.01 & 0.39 & 1.58 & 0.2 & 8.10 & 0.000 \\
\hline 23 & 1.03 & 0.387 & 1.83 & 0.155 & 1.90 & 0.143 & 1.22 & 0.312 & 4.42 & 0.008 & 1.07 & 0.371 \\
\hline 24 & 0.36 & 0.783 & $\star$ & $*$ & 0.62 & 0.6 & 2.30 & 0.0 & 0.93 & & 2.13 & 0.110 \\
\hline 25 & 0.35 & 0.791 & * & * & 0.77 & 0.516 & 9.08 & 0.000 & 11.5 & .000 & 11.6 & 0.000 \\
\hline 26 & $*$ & * & 0.54 & 0.659 & 0.76 & & 1.84 & & & & & 0.111 \\
\hline 27 & 0.28 & 0.840 & & & 1.50 & 0.2 & 0.68 & $0.5^{\prime}$ & 3.80 & 0.01 & 1.49 & 0.230 \\
\hline 28 & 13.97 & 0.0 & 0.52 & & & & & & & & 0.56 & 0.641 \\
\hline 29 & 06 & 0.0 & 0.65 & & 2. & 0.1 & 3.37 & 0.0 & 3.51 & 0.0 & 4.36 & 0.009 \\
\hline 30 & & & & & & & & & & & & 0.140 \\
\hline 31 & & 0.00 & 1.28 & & 0.74 & 0.534 & 2.22 & 0.1 & 0.73 & 0.5 & 4.15 & 0.011 \\
\hline 32 & & & & & & & & & & & & 0.002 \\
\hline 33 & 2. & 0.10 & 0.58 & 0.6 & 2.83 & 0.050 & 0.57 & 0.63 & 1.60 & 0.2 & 1.71 & 0.178 \\
\hline 34 & & & & & & & & & 0.90 & 0.44 & 4.08 & 0.013 \\
\hline 35 & 7.68 & 0.000 & 1.65 & 0.193 & 0.68 & 0.568 & 2.61 & 0.640 & 1.20 & 0.321 & 3.62 & 0.021 \\
\hline \multicolumn{13}{|c|}{ Statistics for the seasonal components } \\
\hline 1 & 5.23 & 0.002 & 1.26 & & & & 2.87 & & 1.91 & & 2.11 & 0.097 \\
\hline 2 & & & & & & & 7.83 & & 1.11 & 0.3 & 0.38 & 0.823 \\
\hline 3 & 99 & & 1.44 & & & & & & & & 3.14 & 0.024 \\
\hline 4 & & & & & & & 0.43 & & 1.10 & 0.36 & 1.83 & 0.141 \\
\hline 5 & 1.98 & 0.11 & & & & & & & 1.21 & & 3.07 & 0.026 \\
\hline 6 & & & & & & & 2.01 & 0.11 & 0.96 & 0.43 & 2.57 & 0.051 \\
\hline 7 & 5.42 & 0.0 & 1.17 & & & & & & & & & \\
\hline 8 & & & & & & & 0.61 & 0.6 & 0.85 & 0.5 & 0.81 & 0.524 \\
\hline 9 & & 0.00 & 0.19 & & & & & & & & 0.54 & \\
\hline 10 & & & & & 1.49 & 0.22 & 3.25 & 0.0 & 0.48 & 0.7 & 0.61 & 0.658 \\
\hline 11 & & 0.00 & 1.01 & & 4.59 & & & & & & & \\
\hline 12 & & 0.000 & 0.81 & & & & & & & 0.3 & 1.50 & 0.220 \\
\hline 13 & 6.41 & 0.000 & 0.40 & & & & & & & & 1.26 & 0.301 \\
\hline 14 & 6.42 & 0.000 & 0.54 & & 0.71 & 0.5 & 0.43 & 0.78 & 2.05 & 0.105 & 1.51 & 0.215 \\
\hline 15 & 3.59 & 0.013 & 1.23 & & & & & & 4.07 & & 1.29 & 0.290 \\
\hline 16 & 2.71 & 0.043 & 0.81 & 0.528 & 2.45 & 0.060 & 1.55 & 0.205 & 1.13 & 0.357 & 0.70 & 0.596 \\
\hline
\end{tabular}


Appendix (continued)

\begin{tabular}{|c|c|c|c|c|c|c|c|c|c|c|c|c|}
\hline \multirow[b]{2}{*}{ Station } & \multicolumn{2}{|c|}{$\begin{array}{l}\text { Purple-capped } \\
\text { Fruit-dove, } \\
\text { Ptilinopus } \\
\text { porpbyraceus }\end{array}$} & \multicolumn{2}{|c|}{$\begin{array}{c}\text { Pacific } \\
\text { Pigeon, } \\
\text { Ducula } \\
\text { pacifica }\end{array}$} & \multicolumn{2}{|c|}{$\begin{array}{l}\text { Collared } \\
\text { Kingfisher, } \\
\text { Halcyon } \\
\text { cbloris }\end{array}$} & \multicolumn{2}{|c|}{$\begin{array}{c}\text { Samoan } \\
\text { Starling, } \\
\text { Aplonis } \\
\text { atrifusca }\end{array}$} & \multicolumn{2}{|c|}{$\begin{array}{c}\text { Cardinal } \\
\text { Honeyeater, } \\
\text { Myzomela } \\
\text { cardinalis }\end{array}$} & \multicolumn{2}{|c|}{$\begin{array}{c}\text { Wattled } \\
\text { Honeyeater, } \\
\text { Foulebaio } \\
\text { carunculata }\end{array}$} \\
\hline & $F$ & $P$ & $F$ & $P$ & $F$ & $P$ & $F$ & $P$ & $F$ & $P$ & $F$ & $P$ \\
\hline 17 & 3.95 & 0.008 & 0.26 & 0.902 & 0.57 & 0.689 & 1.94 & 0.121 & 5.37 & 0.001 & 0.91 & 0.469 \\
\hline 18 & 5.33 & 0.001 & 5.38 & 0.001 & 1.39 & 0.253 & 4.52 & 0.004 & 1.70 & 0.167 & 2.28 & 0.076 \\
\hline 19 & 2.08 & 0.101 & 4.83 & 0.003 & 0.70 & 0.594 & 3.33 & 0.018 & 8.00 & 0.000 & 8.15 & 0.000 \\
\hline 20 & 4.81 & 0.003 & 2.14 & 0.092 & 1.72 & 0.162 & 4.09 & 0.007 & 6.49 & 0.000 & 5.71 & 0.001 \\
\hline 21 & 1.52 & 0.214 & 1.00 & 0.418 & 1.24 & 0.310 & 0.70 & 0.597 & 0.47 & 0.754 & 0.73 & 0.574 \\
\hline 22 & 0.78 & 0.544 & 1.00 & 0.418 & 0.39 & 0.815 & 1.38 & 0.258 & 2.22 & 0.083 & 0.67 & 0.619 \\
\hline 23 & 0.49 & 0.742 & 1.00 & 0.418 & 1.93 & 0.123 & 1.97 & 0.117 & 0.52 & 0.722 & 0.58 & 0.678 \\
\hline 24 & 0.83 & 0.513 & * & * & 0.07 & 0.990 & 0.80 & 0.532 & 0.76 & 0.559 & 2.22 & 0.083 \\
\hline 25 & 1.05 & 0.393 & * & * & 0.65 & 0.628 & 1.43 & 0.240 & 0.34 & 0.849 & 0.80 & 0.534 \\
\hline 26 & * & * & 1.04 & 0.401 & 1.71 & 0.167 & 0.50 & 0.733 & 1.11 & 0.364 & 1.35 & 0.268 \\
\hline 27 & 0.84 & 0.505 & * & * & 0.78 & 0.543 & 1.81 & 0.145 & 2.11 & 0.097 & 0.96 & 0.438 \\
\hline 28 & 1.68 & 0.174 & 0.95 & 0.445 & 1.16 & 0.344 & 0.18 & 0.945 & 1.09 & 0.372 & 1.80 & 0.147 \\
\hline 29 & 0.77 & 0.553 & 1.05 & 0.396 & 0.33 & 0.858 & 1.11 & 0.365 & 0.60 & 0.662 & 5.82 & 0.001 \\
\hline 30 & 1.49 & 0.223 & 0.41 & 0.803 & 3.64 & 0.013 & 2.09 & 0.100 & 2.19 & 0.087 & 1.08 & 0.381 \\
\hline 31 & 5.13 & 0.002 & 1.50 & 0.220 & 0.51 & 0.730 & 1.35 & 0.269 & 0.35 & 0.844 & 1.19 & 0.328 \\
\hline 32 & 7.01 & 0.000 & 1.68 & 0.174 & 1.14 & 0.351 & 2.71 & 0.043 & 1.65 & 0.180 & 3.47 & 0.015 \\
\hline 33 & 3.52 & 0.015 & 2.10 & 0.098 & 0.04 & 0.997 & 1.36 & 0.264 & 2.86 & 0.035 & 0.63 & 0.645 \\
\hline 34 & 4.86 & 0.003 & 1.26 & 0.300 & 0.87 & 0.491 & 1.11 & 0.363 & 4.36 & 0.005 & 3.23 & 0.022 \\
\hline 35 & 4.75 & 0.003 & 2.30 & 0.075 & 1.66 & 0.177 & 2.49 & 0.058 & 2.28 & 0.078 & 6.04 & 0.001 \\
\hline
\end{tabular}

$F$ statistics and $P$ values of regression equations for each species at each station $(P$ values of 0.05 or less are shown in boldface to permit visualization of the distribution of these values among species and stations. The three most abundant species [Wattled Honeyeater, Samoan Starling, and Purple-capped Fruit-dove] have the greatest number of stations with significant statistics, and less abundant species have fewer. However, the level of significance is unrelated to recorded abundance at individual stations (Freifeld 1998). A significant interannual trend may reflect an increase or decrease over time, or it may reflect incidental occurrence of a species at a particular station. Stations where no birds were recorded are denoted by an asterisk.) 